\title{
アドヴァンスド燃料核融合の展望
}

百田弘

(名古屋大学プラズマ研究所)

( 1989 年 1 月10日受理 )

\section{A Review of Advanced Fuel Fusion}

\author{
Hiromu Momota
}

(Received January 10, 1989)

\begin{abstract}
Comparative studies of various fusion fuel cycles show that $\mathrm{p}-{ }^{11} \mathrm{~B}$ and ${ }^{3} \mathrm{He}-{ }^{3} \mathrm{He}$ fuel cycles which yield no neutron need more studies before acceptance as fusion fuels. $\mathrm{D}-{ }^{3} \mathrm{He}$ fuel cycle appears to be most attractive. Because of very rare terrestrial resources, breedings of ${ }^{3} \mathrm{He}$ were so far studied. The recent discovery of lunar ${ }^{3} \mathrm{He}$ changed the whole picture for advanced fuels. A program of studying a $\mathrm{D}-{ }^{3} \mathrm{He} / \mathrm{FRC}$ fusion is just started as a US-Japan collaboration program. As a result, interdisciplinary collaborations between space and fusion research are strongly recommended to develop advanced fuel fusion.
\end{abstract}

Keywords :

advanced fuel, helium 3, field-reversed configuration, commercial fusion reactor,

1. はじめに

核エネルギーを人類の将来に役立たせるべく, 米国・ソ連・日本・ヨーロッパ共同体などを中心とする世 界各国は制御核融合の実現のために過去 35 年余にわたって多くの努力を払ってきた。ての開発は当初に想 定されていたよりも困難であり，とくに燃料の超高温プラズマの閉込めを実現するためには数多くの基礎的 研究と研究開発との蓄積が必要とされたが, 昨今の研究結果はてれら研究が全体として順調に進展しているこ とを示している。事実，米国・日本・ヨーロッパ共同体等で開発されたそれぞれの大型トカマク装置による 実験は超高温プラズマの発生とその閉込めに多大の成果を挙げ，なかでもヨーロッパ共同体が開発したトカ マク装置：JETでは高密度で摂氏 1 億度の超高温プラズマを生成し, それを比較的長時間にわたって閉じ込

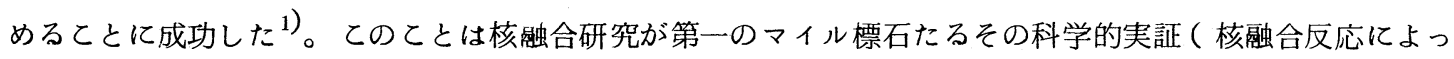


て得られるエネルギーが燃料プラズマからのエネルギー損失を上まわり得るととを実験的に確証するてと） にあと一歩のとてろにまで到達したととを意味している。

このような核融合研究の最近の成果にもかかわらず，商用核融合炬の開発のためには克服しなければなら ない課題が未だに山積している。第一世代の核融合は点火が最も容易な D一T然料によるものと一般には考え られているが，てれによって得られる核融合エネルギーの $80 \%$ を占める $14 \mathrm{MeV}$ 中中性子は炬壁材料に脆化 やヴォイドによる膨脹その他の悪影響をあたえる $\left.{ }^{2}, 3\right)$ 。乙れらの腐蝕に耐えて，経済的に十分な寿命をもつ 炉壁材料の開発がまず必要である。また経済的に電力を供給する核融合炉のためには，例えばトカマク型核 融合炉の場合, 炉心プラズマのベータ值を10数\%程度に向上させるととと平方メートル当たり $10 \mathrm{MW}$ 程度もの高い中性子壁負荷に耐えうるトリチウム増殖ブランケットを開発するととが必要である ${ }^{4}$, 5)。乙れら の為の研究と並行して, 新たなプラズマ閉じ込め方式を開発するてとでてれらトカマク型商用核融合炉の諸 課題を緩和しようとする, アドヴァンスド閉じ込め方式による核融合の研究が多くの研究機関で研究さ れている。また他方, 種々の課題が $\mathrm{D}$ - T核反応に伴う $14 \mathrm{MeV}$ 中性子に起因するとてろから, D-T 核 融合を避けて，中性子の発生がより少ない燃料による核融合を開発しょうとする，いわゆるアドヴァン スド然料核融合の研究が遂行されている。とくに後者の研究は最近の月表面でのヘリウム 3 の発見に刺 激されて急速に活気をおびてきた。以下，てのアドヴァンスド然料核融合の研究を概観し，今後の展望を試みる。

2 章では考え得る核融合反応について，それぞれの商用核融合炬としての特長とそれを実現するために必要 とされるプラズマの点火条件を比較する。重水素一ヘリウム 3 燃料サイクルは最も魅力的と考えられる。陽 子一ボロン 11 や陽子ーリチウム 6 核融合はヘリウム 3 -ヘリウム 3 核融合と同様に $14 \mathrm{MeV}$ 中性子を発生 しないので魅力的ではあるが自己点火せず，てれらを炬として役立たせるには何等かの抜本的な手法の開発 が必要とされる。地球上でのヘリウム 3 資源は実用化には余りにも稀少なので,てれまで何等かの方法で ヘリウム 3 を増殖する燃料サイクルが検討されてきた。3章では, てれらの検討結果を紹介し，そてに現れたアド ヴァンスド燃料核融合の特長と問題点とを概観する。最近の月表面へリウム 3 資源の発見はアドヴァンスド 然料核融合の研究を大きく変化させた。4 章ではこの月表面へリウム 3 資源とその経済性を紹介し，てのへリ ウム 3 を燃料とする商用核融合炬の可能性と今後の検討課題を 5 章で論じる。

\section{2. アドヴァンスド燃料サイクルとその物理的要請}

アドヴァンスド燃料核融合は D-T 核融合が遭遇する㮔々の課題を緩和すべく表 1 亿示すような発熱核反

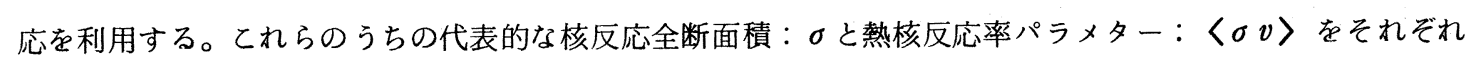
図 1 と図 2 に示す ${ }^{6)}$ 。比較のために揭げた D-T 核反応は $108 \mathrm{keV}$ に第一エネルギーをもつ複合核反応で, 低いエネルギーで大きな核反応全断面積をもっている。D-D核反応は障壁因子が小さいので比較的ひく いエネルギーでもある程度の值の核反応断面積であるが, 大きな共鳴は認められず,したがって核反応断面積 
の最大值はそれほど大きくはない。 $\mathrm{D}-{ }^{3} \mathrm{He}$ 核反応は $400 \mathrm{keV}$ に鋭い共鳴があり, 核反応全断面積が比較 的大きなものになっている。乙れらの他の高Zの核反応，たとえばp- ${ }^{11} \mathrm{~B} や{ }^{3} \mathrm{He}-{ }^{3} \mathrm{He}$ などはいずれも障 壁因子が大きく，したがって核融合反応率をあるていど大きくするためにはより高い粒子エネルギーが 必要とされる。

これらの核反応を利用したアドヴァンスド然料サイクルを表 2 に掲げる。この表の第一のグループは重水 素燃料を基礎としたもので，触媒 $\mathrm{D}-\mathrm{D}^{7} ， \mathrm{DD}-{ }^{3} \mathrm{He}{ }^{8,9)}$ やD $-{ }^{3} \mathrm{He}$ 乃至はてれらを組合せた共生系 ${ }^{10 ）}$ 等 は比較的現実的なアドヴァンスド然料サイクルの可能性があると考えられた。図 3 は触媒 $\mathrm{D}-\mathrm{D}$ と $\mathrm{DD}-{ }^{3} \mathrm{He}$ 燃料サイクルを図示したものである。触媒 $\mathrm{D}$-D然料サイクルは D-D反応で発生するトリチウムとへリウ ム 3 と党炉心プラズマからの排ガスから分離して, 核融合反応を増加させるべく炬心プラズマに再注入する。 $\mathrm{DD}-{ }^{3} \mathrm{He}$ 燃料サイクルは $14 \mathrm{MeV}$ 中性子の発生を 抑えるためにトリチウムの再注入を止め，乙れを貯 蔵にまわして, 半減期が12.6年のベータ崩壊によって貯 表 2. 各種燃料サイクル

蔵器で得られるリチウムるを炉心プラズマに注入する, いわば触媒 $\mathrm{D}-\mathrm{D}$ 然料サイクルの改良型である。ア ドヴァンスド燃料サィクルの第二のグループは陽子 またはへリウム 3 基礎としたもので，てれらの中 で $-{ }^{11} \mathrm{~B}{ }^{3} \mathrm{He}-{ }^{3} \mathrm{He}$ 然料サィクルは中性子を全く 発生しないという利点があり，究極の核融合燃料サ イクルと目されている。

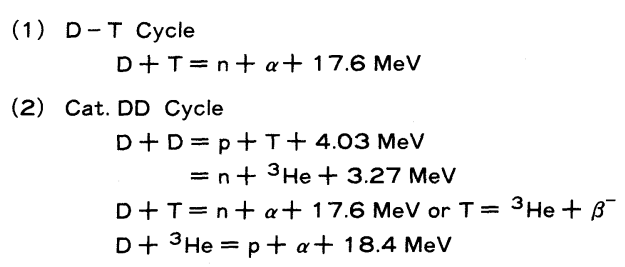

(1) $D-T$ Cycle

$$
\mathrm{D}+\mathrm{T}=\mathrm{n}+\alpha+17.6 \mathrm{MeV}
$$

(2) Cat. DD Cycle

$D+D=p+T+4.03 \mathrm{MeV}$

$=\mathrm{n}+{ }^{3} \mathrm{He}+3.27 \mathrm{MeV}$

$\mathrm{D}+\mathrm{T}=\mathrm{n}+\alpha+17.6 \mathrm{MeV}$ or $\mathrm{T}={ }^{3} \mathrm{He}+\beta^{-}$

$\mathrm{D}+{ }^{3} \mathrm{He}=\mathrm{p}+\alpha+18.4 \mathrm{MeV}$

(3) $\mathrm{p}^{11} \mathrm{~B}$ Cycle

$\mathrm{p}+{ }^{11} \mathrm{~B}=3 \alpha+8.7 \mathrm{MeV}$

(4) $\mathrm{p}^{6} \mathrm{Li}$ Cycle

$\mathrm{p}+{ }^{6} \mathrm{Li}={ }^{3} \mathrm{He}+\alpha+4.02 \mathrm{MeV}$

a)

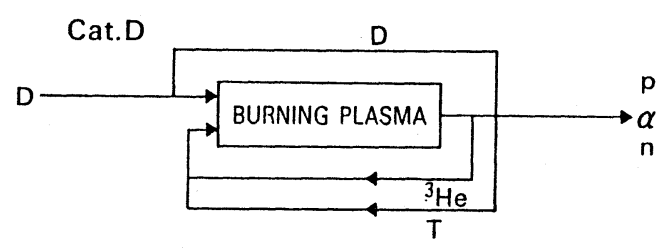

b)

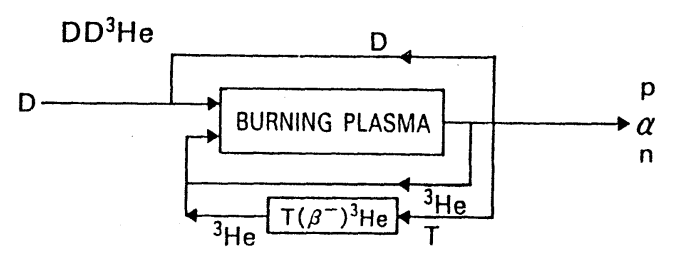

図 3. 触媒 D-D (a) とDD- ${ }^{3} \mathrm{He}(\mathrm{b})$ 燃料サイクル 
さて，定常核然焼プラズマにあっては，然料プラズマへの単位時間あたりの加熱エネルギー（荷電粒子に よって運ばれる核融合エネルギーとプラズマ外からの加熱入力）は然料プラズマからのエネルギー損失（プ ラズマ・エネルギーの放射損失と伝導損失) と釣合っている。 D-T 熱核融合の場合，熱核反応率パラメター： $\langle\sigma v\rangle$ 用いて単位時間あたりの核融合エネルギーを評価し，プラズマからの放射損失を制動放射で近似す るととによってての条件はプラズマが自分自身で反応を維持する条件，いわ的点火条件 ${ }^{11)}$ となる。プラズ マ外からの入力エネルギーの助けで核燃焼を維持するいわゆるビーム駆動核融合の場合には，ビームのエネ ルギーを最適化し，いわゆる二成分効果を利用して，核融合エネルギーの増倍をはかることが可能である。 核融合出力とプラズマ外からの加熱入力との比： $Q_{p}$, 炬心プラズマの電子密度 : $n$, エネルギー閉じ込め 時間 : $\tau$, 平均温度 : $T$ を導入し， $Q_{p}$ を最大にすべく他のプラズマ・パラメター等を最適化してえられる $Q_{p}$ を 三重積 $: n \tau T$ の関数として図示したものが図 4 である ${ }^{13)}$ 。 $Q_{p}$ が比較的小さいときは二成分効果が顕著で 核融合出力が大幅に増大するが，乙の値がある程度大きくなると二成分効果は実質的には無効となる。アド
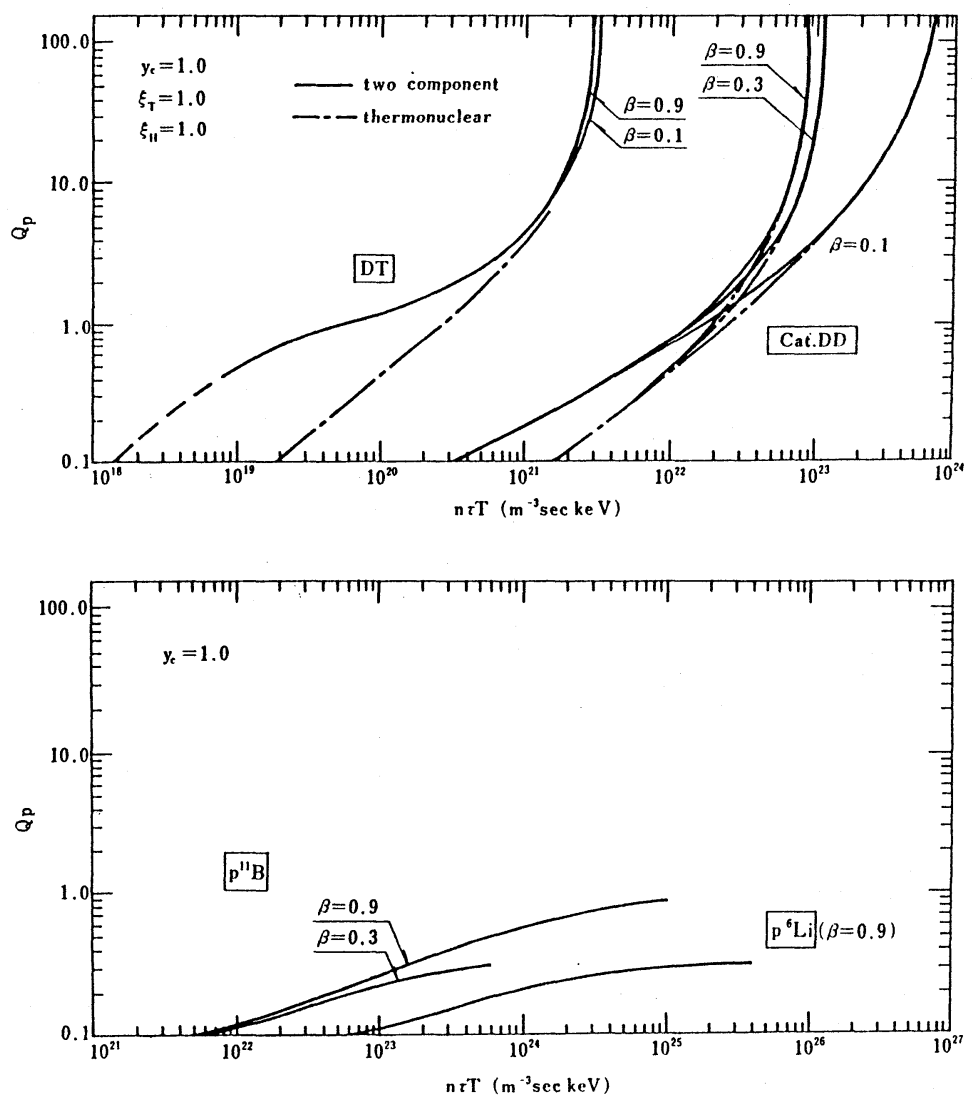

図 4. 三重積： $n \tau T$ と最大エネルギー利得： $Q_{p}$ 
ヴァンスド燃料核融合の場合, 炬心プラズマの動作温度が高いので核反応生成荷電粒子と電子との衝突 にたいして然料原子核との弾性核散乱が比較的顕著になって然料プラズマに高エネルギー成分が形成さ れ，てれによって核融合反応率が熱核反応の場合よりも増加する ${ }^{14)}$ 。動作温度が高いととはプラズマか らのシンクロトロン放射損失を増大させ ${ }^{15)}$, さらに電子の相対論的効果にもとづく四重極放射の寄与が 無視できなくなり制動放射損失が増大する16)。乙れらの効果を取り入れ，種々のアドヴァンスド然料核 融合で得られる $Q_{p}$ の最大值を三重積： $n \tau T$ の関数として, さきと同様に図示したものが図 4 に与えられ ている ${ }^{17)}$ 。触媒 $\mathrm{D}-\mathrm{D}, \mathrm{DD}-{ }^{3} \mathrm{He}$ と $\mathrm{D}^{3} \mathrm{He}$ はいずれも自己点火に達しうるが，そのための条件はプラズマ

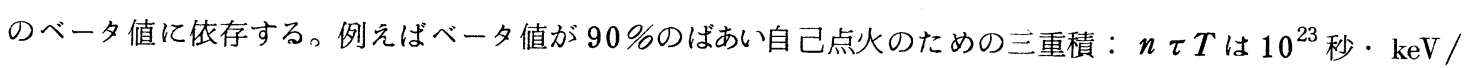
$\mathrm{m}^{3}$ 程度であるが, $10 \%$ \%ベータ值では一桁程度大きな三重積が要求される。てれは超高温のアドヴァンス ド然料核然焼プラズマはシンクロトロン放射損失が大きいためで, 高ベータ・プラズマの生成・閉じ込めを 実現してての放射エネルギーをプラズマに再吸収させるととの重要性を示唆するものである。単純な D-D は核融合エネルギーがてれらのものに比べて数分の一であり, 自己点火のための三重積 : $n \tau T$ も数倍大きな 值が要請される。 $\mathrm{D}-{ }^{6} \mathrm{Li}, \mathrm{p}-{ }^{6} \mathrm{Li}, \mathrm{p}-{ }^{11} \mathrm{~B}, \quad \mathrm{P}^{3} \mathrm{He}-{ }^{3} \mathrm{He}$ 等の然料サイクルは超高温の核反応プラズマ を必要とし，しかもプラズマの実効的 Z 值が大きいので制動放射によるエネルギー損失が大きく，自己点火 を実現するためには何等かの根本的な手法の開発を必要とする。

てれらの燃料サイクルで核融合の自己点火が実現したとき，それが実際に D一T 核融合で直面する諸課題 を回避して魅力的なものになり得るかどうかを予め解析しておくてとは大切である。この目的で然料サイク ルにたいする評価関数として，中性子の割合い(中性子で運ばれるエネルギーの核融合エネルギーに対する 割合い): $f_{n}$, および放射パラメータ（荷電粒子によって直接エネルギー変換器に導入されるエネルギー

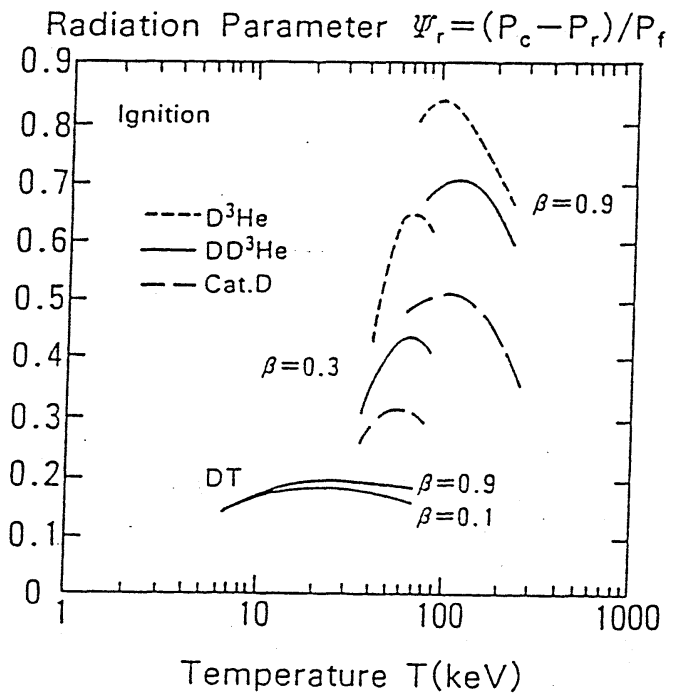

a)
$14 \mathrm{MeV}$ Neutron Fraction. $P_{n}^{14} / P_{f}$

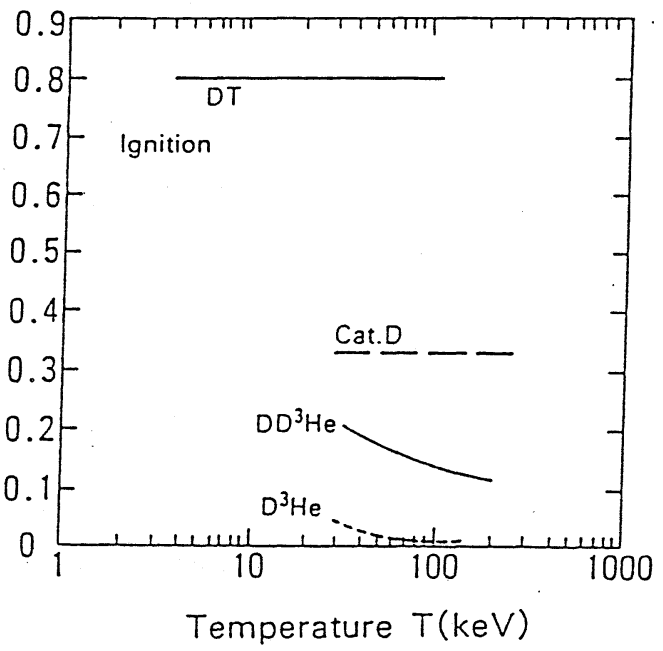

b)

図 5. 各種然料サイクルの中性子の割合い (a) と放射パラメター (b) 
の核融合エネルギーに対する割合い： $\Psi_{\boldsymbol{r}}$ を導入する ${ }^{18)}$ 。アドヴァンスド然料核融合は超高ベータのプラズ マを前提としており，低ベータ・核然焼プラズマで問題になる核融合のエネルギー密度はてのばあいは十分 に大きいので, 結果として核融合のエネルギー密度が核融合炉の経済性を支配する重要な因子にならない。 図 5 は触媒 $\mathrm{D}-\mathrm{D}, \mathrm{DD}-{ }^{3} \mathrm{He}$ と $\mathrm{D}-{ }^{3} \mathrm{He}$ それぞれの燃料サイクルについて，中性子の割合い： $f_{n}$ ，および 放射パラメター : $\Psi_{r}$ をプラズマの平均温度：Tの関数として与えたものである。図 6 はこれらの然料サイ

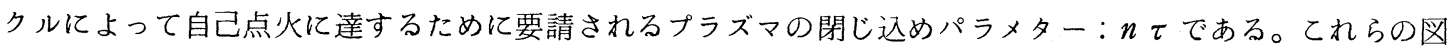
においても D-T 核融合然料サイクルでの值が比較のために与えられている。図 5 によれ゙, 中性子の割合い は触媒 $\mathrm{D}-\mathrm{D}, \mathrm{DD}-{ }^{3} \mathrm{He} ， お よ ひ ゙ \mathrm{D}-{ }^{3} \mathrm{He}$ などの燃料サィクルではそれぞれ $30 \% ， 15 \%$ および $1 \% \%$ 程度

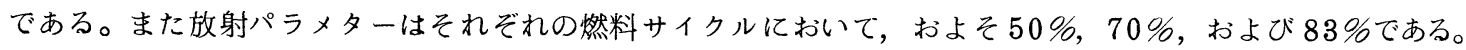
これらの值は，これらの燃料サイクル を利用するととでトリチウム増殖その 他中性子に起因する課題を大幅に軽減 し，しかも高効率の直接エネルギー変 換器の利用の割合いが大きく, 従って 超高プラント効率の核融合炉を構築す る可能性を示唆するものである ${ }^{19)}$ 。表 3 はこれらの然料サイクルによる上記 の解析結果に基づく電気出力百万 $\mathrm{kW}$ の核融合炉の特徵的パラメターの一例 である。なかでも，D- ${ }^{3} \mathrm{He}$ 然料サイ クルは中性子による炉壁材料の腐蝕が全 く問題にならない程度にまで中性子を 減少させ，汃 $78 \%$ 程度もの非常に

Confinement Parameter $n \tau\left(\mathrm{m}^{-3} \mathrm{sec}\right)$

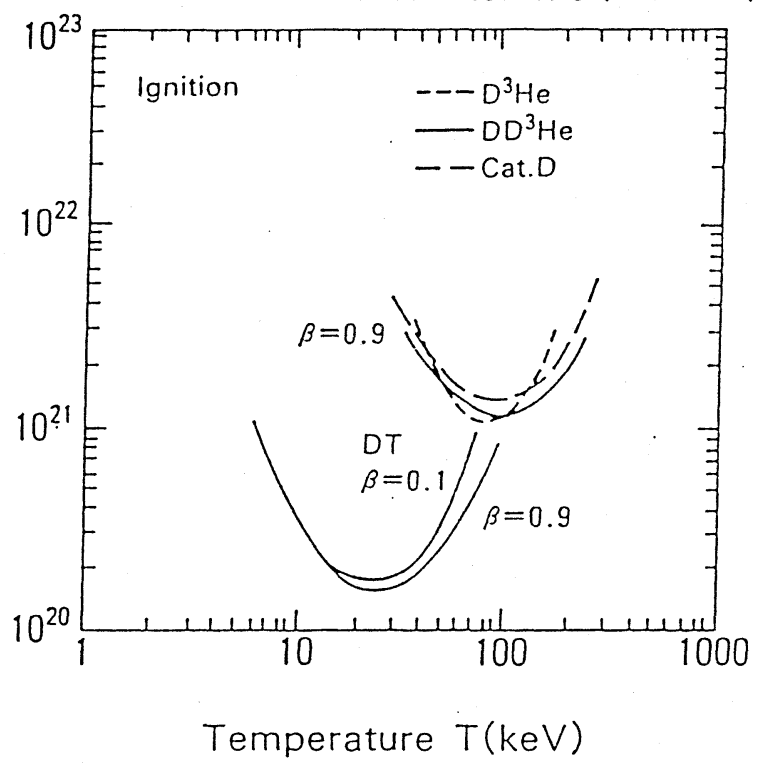

図 6. 各種燃料サイクルの自己点火のための閉じ込めパラメター

表 3 . 各種燃料核融合の特徵的 パラメター (1 GW)

\begin{tabular}{|c|c|c|c|c|}
\hline & D T & Cat. D & $\mathrm{DD}^{3} \mathrm{He}$ & $D^{3} \mathrm{He}$ \\
\hline $\mathrm{T}(\mathrm{keV})$ & 13 & 40 & 100 & 100 \\
\hline $\mathrm{n} \tau\left(\mathrm{sm}^{-3}\right)$ & $2 \times 10^{20}$ & $2 \times 10^{21}$ & $1 \times 10^{21}$ & $1 \times 10^{21}$ \\
\hline $\begin{array}{l}\text { Plant } \\
\text { Efficiency }(\%)\end{array}$ & 45 & 65 & 70 & 78 \\
\hline $\begin{array}{l}14 \mathrm{MeV} \\
\text { Neutrons }\end{array}$ & 1800 & 550 & 215 & 13 \\
\hline $\begin{array}{l}\text { Engineering } \\
\text { Requirement }\end{array}$ & T Beeding & & $\begin{array}{l}300 \mathrm{~kg} \\
\text { T Bank }\end{array}$ & $\begin{array}{l}50 \mathrm{~kg} / \mathrm{y} \\
3 \mathrm{He} \text { Fuel }\end{array}$ \\
\hline
\end{tabular}


高いプラント効率をもたし得るもので, 非常に魅力的である。が, 温度が $100 \mathrm{keV}$ 超高べータの重水素ーヘリ ウム 3 プラズマを $10^{21}$ 秒 $/ \mathrm{m}^{3}$ 程度閉じ込めるととがその前提である。

\section{3. アドヴァンスド燃料核融合炉概念}

前節で種々のアドヴァンスド然料サイクルを紹介し，それらの物理的要請を論じた。そして，結果として， $\mathrm{D}^{-}{ }^{3} \mathrm{He}$ 燃料サイクルが商用核融合炬として最も魅力的なものの一つであるととを知った（表 3 ）。燃料の ヘリらム 3 は $1 \mathrm{~kg}$ あたり $1 \mathrm{M} \$$ 程度( トリチゥムの十分の一)の価格で購入するととが可能であるが, その 生産量は非常にわずかである。例えばマントルからのへリウムガスからのへリウム 3 はせいぜい年間 $3 \mathrm{~kg}$ 程度, また核兵器のトリチウムのベータ崩壊から得られるへリウム 3 年間 $15 \mathrm{~kg}$ 程度のものである。表 3 にみられるように，百万 $\mathrm{kW}$ の発電炉は年間 $50 \mathrm{~kg}$ のヘリウム 3 燃料を消費するという視点からは，へリウ ム 3 燃料は地球上には事実上存在しないと言っても間違いではない。いっほう触媒 D-D 燃料サイクルは重 水素のみを然料とするので然料資源に関しては全く問題はない。トリチウム増殖ブランケットも不必要なの で，ブランヶット構成の自由度がふえるという大きな利点は失われない。ての触媒 D-D 然料サイクルを用

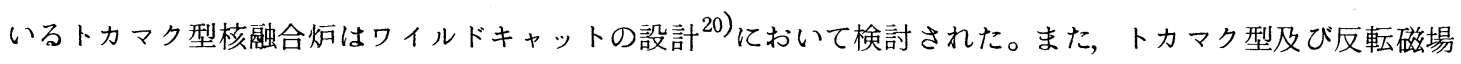
ピンギで D一T燃料サィクルを用いる場合と触媒 $\mathrm{D}-\mathrm{D}$ 燃料サィクルを用いる場合との経済性や技術的課題 等についての評価がおてなわれた ${ }^{21)}$ 。低ベータ・トカマクに触媒 D-D燃料サイクルを用いたとき，トリチ ウム增殖ブランヶットが不要という利点がある反面, 核融合の出力密度が低いので, 核融合炬は相対的に大 型になり商用核融合炬としての経済性が損われる。比較的ベータ值の大きな反転磁場ピンチに触媒 D-D燃 料サイクルを用いたものは，D一T然料の場合よりも強い磁場と大電流駆動が必要ではあるが，商用核融合 炬としてはより経済性に富むととが示された。ての核融合炉の課題は $14 \mathrm{MeV}$ 中性子が三分の一に減少するとは いうものの, プラズマからの放射と荷電粒子の第一壁への負荷が非常に大きくなるというととである。第二安定領 域で作動するトカマク型のアドヴァンスド然料核融合 ${ }^{22)}$ は反転磁場ピンチの場合と類似しているものと思われる。

$\mathrm{D}-{ }^{3} \mathrm{He}$ 然料サィクルは触媒 D-D 然料サィクルに比べてょり理想に近いものではあるが，地上での然料 資源は望みえない。そこで方策として，ヘリウム３在増殖するてとが考えられる。その一つが先に紹介した $\mathrm{DD}-{ }^{3} \mathrm{He}$ 燃料サィクルである。重水素一ヘリウム 3 超高ベータ・プラズマの温度を $70 \sim 100 \mathrm{keV}$ 程度まで 高くすると， D- ${ }^{3} \mathrm{He}$ 核反応が D-D核反応より優位になるので，図 5 に示されたように放射パラメータは 40〜70\%もの高い值を示し中性子の割合いは13～15\% 程度にまで減少する。とのとき核融合パワーの半分程 度かそれ以上のパワーを処理しうる大容量の直接エネルギー変換器の設置が可能でなければならず，てのた め，ての燃料サイクルにとってミラー型や磁場反転配位などの直線型プラズマ閉じ込めは必至である。磁場 反転配位はての要件を満たしており，研究は未だ初等的とはいえ実験室では50〜100\%もの超高ベータ. プラズマが得られている ${ }^{23)}$ とから，てれと DD- ${ }^{3} \mathrm{He}$ 燃料サイクルとを組合せた商用核融合炉の概念設㳬 がおてなわれた。表 4 は核融合出力 $1 \mathrm{GW}$ の核融合炉の主要パラメータである。プラズマの体積は約 30 立 
表 4. $1 \mathrm{GW} \mathrm{DD}-{ }^{3} \mathrm{He} / \mathrm{FRC}$ 核融合の特徵的パラメータ

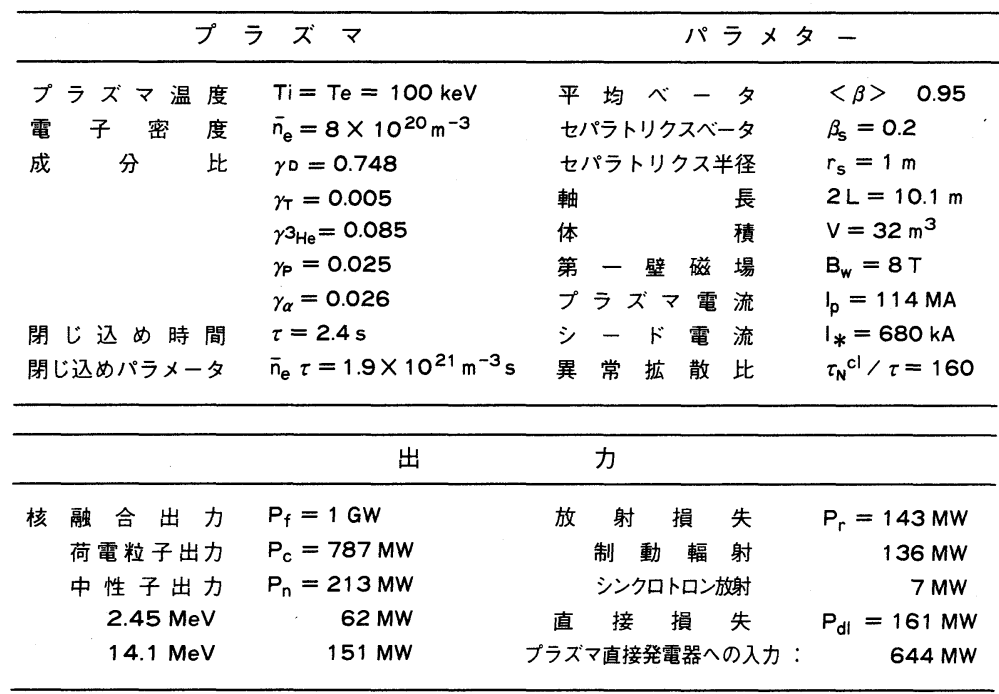

方米とコンパクトであるが直径 30 米の一対の直接エネルギー変換器と $300 \mathrm{~kg}$ のトチウム貯蔵庫が必要で ある。技術面からは大いに魅力的なとの核融合炉も，実現にいたるまでのプラズマ物理の面での多くの研究 努力が必要である。

ヘリウム 3 を增殖するいまひとつの方法はへリウム 3 燃料生産炬と電力生産炬とからなる共生システムを 構築するととである ${ }^{10)}$ 。燃料生産炬としては触媒 $\mathrm{D}-\mathrm{D}$ 核融合炉を採用し，そてで発生するへリウム 3 は再 注入せずに電力生産のためのサテライト核融合炬に般入する。重水素一ヘリウム 3 燃料を用いるこの都市型 サテラィト核融合炬はやはり超高ベータ・プラズマで大容量の直接エネルギー変換器を必要とするとてろか ら，磁場反転配位やタンデム・ミラーなどで燃料プラズマを閉じ込める方式が検討された ${ }^{25,26)}$ 。前者はサフ アイアと名付けられた数干 $\mathrm{kW}$ の電気出力小型核融合炬の設計で中性粒子ビーム入射にって定常運転を維 持する，いわゆるビーム駆動型である。 $Q_{p}$ 值は 30 程度であるが, 放射パラメターの大きい燃料サィクルと 高効率の直接エネルギー変換を採用するととによって $50 \%$ の高い総合プラント効率が得られており，小 型であるにも拘らず他の然料サイクルによる大型の核融合炉と同程度の経済性が見込まれた。タンデム・ ミラーを用いた重水素ーヘリウム 3 燃料サテライト核融合炬の設計では偏極核反応を利用 ${ }^{27)} し て D-D$ 核反応を抑えるととによって，人間の手による炉の維持を可能にするとともに中性子シールドを無くし て磁場コイルを大幅に縮小するてとが試みられた。こてらの炬設計も炉技術の観点からはそれぞれに魅 力あるものと考えられるが, 燃料生産炬は触媒 D-D 核融合炬の採用が想定されており, 主として $14 \mathrm{MeV}$ 中性子に起因する本来の問題を解決していないので, グローバルには依然課題がのてされている。 


\section{4. 月表面のヘリウム 3 資源}

米国の月探索ロケット：アポロ 10，12，17等の持ちかえった月表面の泥のサンプルとルナ( ソ連)の行 つたプローブ測定等の最近の分析結果は月表面の泥に採鉱しうろへリウム 3 が大量に含まれているてとを明 らかにした ${ }^{28)}$ 。この発見は非常に大切で，てれまでへリウム 3 の増殖を前提としてきたアドヴァンスド燃料

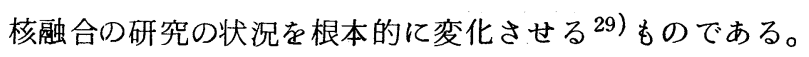

月表面の ${ }^{3} \mathrm{He}$ の起源は太陽の高重力圈での $D(p, r){ }^{3} \mathrm{He}$ 反応である。とてで発生したへリウム 3 は平 均 $450 \mathrm{~km} /$ 秒の速さの太陽風にのって放出される。ててでのへリウム流束は $6 \times 10^{10} \mathrm{atom} / \mathrm{m}^{2} \cdot$ 秒程度, ヘリウム 3 とヘリウム 4 の比は $480 \mathrm{appm}$ 程度である。月表面はてのへリウムを40億年以上の歳月 にわたって集収し続けてきた。大陽風の粒子は月表面の泥の表面から $0.02 \mu \mathrm{m}$ 程度以内の深さに 注入されるので，泥の粒が微細であるほど単位重量に多量のへリウムを集収する。ての意味で，たえずいん 石によって粉砕されて月表面の全域 5-15 mの深さにわたって 80\%の重量比で存在する 8-125 $\mu \mathrm{m}$ の超 微細粒子の泥は非常に効率的なへリウムのコレクターである。月表面の泥に含まれるへリウムの割合いはサ ンプルによってばらついている。サンプルでのヘリウム 3 とヘリゥム 4 の比は拡散における同位体効果によ って $10 \%$ 程度減少している。海の泥の $10 \%$ を占めているチタン鉄鉱はへリウム 4 をより高密度に含んでいる ので月表面の $20 \%$ をしめる海では 5 米の深さにわたって平均 $30 \mathrm{ppm}$ ，丘陵では 10 米の深さにわたって平均 $7 \mathrm{ppm}$ 程度のヘリウム密度と推定され, 月表面全体で, 太陽風にたいする幾何学的効果をも考虑にいれ て評価した結果， $10^{6}$ トン以上の採鉱しうるへリウム 3 が存在するものと結論される。なお，ての量は 月表面全体のヘリウム 3 の含有量の $1 \%$ 以下である。地球よりも外軌道の惑星 : 木星や土星は $25 \mathrm{wt} \%$ 程 度のヘリウムがあると考えられている30)。従って, そてでのへリウム 3 とへリウム 4 との比が $140 \mathrm{appm}$ 程度と洘えれば，てれらの惑星でのへリウム 3 資源は $10^{20}$ トン以上と見積もられる。

21 世紀初頭の月面基地を利用した月表面ヘリウム 3 の採鉱と地球への輸送のシナリオが提案された ${ }^{28)}$, 31) 地球から運搬するプラント機器の耐用年数は 10 年であると仮定して,ヘリウム 3 を得るためのプラント機器 の運般，採鉱，昼時間の高温度（摂氏 130 度）を利用する 600 度での脱ガス, 夜時間の低温度 ( 零下 120 度）を利用する蒸溜と超流動によるへリウ

ム 3 の分離, シャトルとよる地球への輸送 などのエネルギーが算定された（表 5 ）。 これによると，1 kgのヘリウム 3 を地球上 で得るために要するエネルギーは $2382 \mathrm{GJ}$ である。ヘリウム 3 を燃料として核融合に 役立たせることが可能となれば， $1 \mathrm{~kg}$ のへ リウム 3 は $6 \times 10^{5} \mathrm{GJ}$ のネルギーを生産 する。てれらの試算によれば月表面のへリ
表 5. 月表面ヘリウム 3 採取・運搬に要するエネルギーコスト

\begin{tabular}{|c|c|}
\hline & $\begin{array}{c}{ }^{3} \mathrm{He} \\
(\mathrm{GJ} / \mathrm{kg})\end{array}$ \\
\hline Mining ( 120,000 tonnes of soil) & 2200 \\
\hline Gas evolution ( 20,000 tonnes of soil) & \\
\hline ( $100 \%$ solar energy plus $50 \%$ reheat) & 180 \\
\hline Isotope separation & \\
\hline (superleak plus distillation) & 1 \\
\hline Transportation & 1 \\
\hline Total & 2382 \\
\hline
\end{tabular}


ウム 3 はエネルギー利得が 200 以上という質の高いものであり，その量も $10^{7} \mathrm{GW}$. 年という魅力的な資源 である。

\section{5. おわりにー アドヴァンスド燃料核融合の展望}

アドヴァンスド然料核融合の展望と題して，歴史を概観してきた。とてで展望を論ずる筈ではあるが， いざとなると筆者自身展望がつかめない。ただアドヴァンスド然料を用いて人類に役立ちうる核融合工 ネルギーを開発すべく，研究努力を重ねるのみである。

アドヴァンスド然料核融合の研究はてれまで主として米国そして若干は日本で遂行され，ソ連やヨーロッ パ共同体にはてれといった研究の蓄積はない。その米国でさえ，エネルギー省でアドヴァンスド然料核融合 の研究が支持されるようになったのは 1985 年の末のととである。すでに概観してきた通り, 理想的なアド ヴァンスド然料のためのプラズマは50\% 程度かそれ以上に高いベータ值をもった，大容量の直接エネルギー変換 器の設置が可能なもので，てれを $100 \mathrm{keV}$ 程度の温度で閉込めパラメータ：10 21 秒/ 立方米だけ閉じ込め るととが要請される。温度と閉じ込めに関しては今後の研究の進歩に期待するととにして，ベータ值と大容 量の直接エネルギー変換器の設置の条件にたいして磁場反転配位（FRC）はての要請に最も合致したものの 一つと考えられる。しかも，重水素一ヘリウム 3 燃料がての磁場反転配位で点火したときには $14.7 \mathrm{MeV} の$ 陽子が選択的に配位内に捕獲されててれが配位の定常的な維持に大きく寄与しうる ${ }^{32)}$ とがわかって，定常 磁場反転配位による重水素一ヘリウム 3 然料が多くの研究者に関心を持たれるようになった。との方向で日 本と米国との共同研究として, D $-{ }^{3} \mathrm{He} / \mathrm{FRC}$ 商用核融合弱の概念設計を遂行し，乙れの開発に不可避の課 題を明らかにし，そして当面着手すべきプログラムを提案する一連のプログラムが発足した。

炬技術的には課題が軽減するとはいえ，例えば D $-{ }^{3} \mathrm{He} / \mathrm{FRC}$ 商用核融合のためのプラズマ物理はてれま でに多くの成果を挙げてきた磁気流体的または旋回中心的なものと全く異なった側面をもっている。超高べ 一タのプラズマが対象となり，またててでは高エネルギー核反応生成荷電粒子の振舞いが本質的に現象に影

響を与え得る。

トカマクや軸対称ミラー型の配位における重水素一ヘリウム. 3 燃料プラズマも今後の研究対象になるもの と考えられる。こてではプラズマを比較的低温度で然焼させ，場合によっては偏極核反応を用いて核反応の 分岐を制御するとと等も研究の対象とされよう。

これまで慣性閉じ込めによるアドヴァンスド然料核融合ははとんど研究の対象とされていなかった。が， アドヴァンスド然料核融合の利点は磁気的閉じ込めのばあいと同様と考えられる。アドヴァンスド燃料核融 合に特有の大容量の直接エネルギー変換器の観点からは慣性閉じ込め方式はより魅力的でさえある。慣性閉じ 込めによるD- ${ }^{3} \mathrm{He}$ 核融合の研究も最近になって, わが日本で着手されるに至った。大いなる進展が期待される。

最後に，てれまで述べてきたことで明らかなように，アドヴァンスド然料核融合の開発は月表面資源の開 発とあいまって夷用にいたるものと考えられる。その意味では, 研究計画の立案, 研究情報の交換, 両分野 
に共通する課題についての共同研究など，核融合研究と宇宙開発の二つの研究分野の協力は，てんで益々密 接になることが期待される。

\section{謝 辞}

この機会を借りて，筆者にアドヴァンスド燃料核融合の重要性を御教示くださり，有効な御指導を賜った 伏見康治先生に心から感謝したい。また秋宗秀夫教授には研究の指針や炉技術の諸課題について，終始御指 導を戴いた。岡本正雄助教授をはじめ，富田幸博氏，野村保之氏その他多数の方々にアドヴァンスド然料核 融合の共同研究を通じて種々御協力を戴いた。そして，イリノイ大学のG.H. マイリー教授には研究の 遂行に関して種々の御支援と御協力を戴いた。てれらの方々にも心から感謝する次第である。

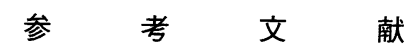

1) JET Group : to be published in Proc. IAEA 12th Conf. on CTR.

2) G. L. Kulcinski : IAEA CN-33/s 3-1 (1975).

3) R. W. Conn : Journ. Nucl. Materials Vol. 76 \& 77 (1978) 103.

4) A. Dabiri et al.: Fusion Technology Vol. 10 (1986) 49. also see : R. A. Krakowski and J. G. Delene : Journ. Fusion Energy Vol. 7 (1988) 49.

5) 宅間 \& 山地：ENERGY 1987-5, 18.

6）より詳しくは R. Feldbacher：INDC (AUS)-12/G (IAEA, Austria : 1987) 参照.

7) R. G. Mills : PPL-TM-259 (PPPL, Princeton : 1971).

8) D. Steiner : Nucl. Sci. Eng. Vol. 58 (1975) 107.

9) H. Momota : Fusion Tech. Vol. 11 (1987) 439.

10) G. H. Miley et al.: Proc. 2nd ANS Topl. Mtg., CONF-760935 (1976) 119.

11) J. R. McNally: Fusion Technology/Fusion Vol. 2 (1982) 9.

12) J. M. Dowson, H. P. Furth, and F. H. Tenny : Phys. Rev. Letters Vol. 26 (1971), 1156.

13) H. Momota, Y. Tomita, and Y. Nomura : IPPJ -460 (IPP, Nagoya : 1980).

14) J. J. Devaney and M. L. Stein : Nucl. Sci. Eng. Vol. 49 (1971) 323. also see : Y. Nakao et al.: Nuclear Fusion Vol. 28 (1988) 1029.

15) J. M. Dowson : PPG-273 (UCLA, Los Angels : 1976).

16) W. J. Chen et al.: Journ. Phys. Soc. Japan Vol. 51 (1981), 1620.

17) H. Momota, Y. Tomita, and Y. Nomura : IAEA-TC-392/35 (IAEA, Vienna : 1983) 3.

18) G. H. Miley : Fusion Energy Conversion (ANS, 1976).

19) H. Momota et al.: Nucl. Inst. /Meth. in Physics Research Vol. A271 (1988) 7.

20) K. E. Evans et al.: ANL/FPP-TM-150 (ANL, Argonne : 1981).

21) R. L. Hagenson and R. A. Krakowski : LA-9139-MS (LANL, Los Alamos : 1982).

22) B. Coppi : private communication.

23) R. E. Siemon, et al.: Fusion Technology Vol. 9 (1986) 13.

24) 岡本 他：IPPJ-DT-129 (IPP, Nagoya : 1986).

25) G. W. Shuy, A. E. Daribi and H. Gurol : Fusion Technology Vol. 9 (1986) 459.

26) J. G. Gilligan, et al. : ANS Top 1. Mtg., COO-2218-172 (King of Prussia : 1980). also see : MARS Interim Design Report, UCRL-53480 (LLNL, Livermore : 1984).

27) R. M. Kulsrud et al. : Phys. Rev. Lett. Vol. 49 (1982) 1248.

28) Wittenberg et al.: Fusion Technology Vol. 10 (1986) 167.

29) J. M. Dowson : Bull. APS 31 (1986) 1498.

30) Landolt-Bornstein Numerical Data, New Series, Vol. 2a-Astronomy and Physics, p. 135 (Springer-Vergrad, Berlin : 1980).

31) R. B. Robert: Bull. APS 31 (1986), 1499.

32) H. L. Berk, H. Momota, and T. Tajima : Phys. Fluids Vol. 30 (1987) 3548. 